\begin{tabular}{|c|c|c|}
\hline Beitr. Ent. & Keltern & ISSN 0005 - 805X \\
\hline $\mathbf{5 1 ( 2 0 0 1 ) 2}$ & S. $517-527$ & 16.12 .2001 \\
\hline
\end{tabular}

\title{
The spatial distribution and plant specificity of Neuropterida in different forest sites in Southern Germany ${ }^{*}$
}

\section{(Raphidioptera and Neuroptera)}

With 6 Tables

AXEL GRUPPE and HOLGER SCHUBERT

\section{Summary}

In Southern Germany the neuropterid fauna of five forest sites was sampled by a set of automatic traps both in the canopy and near the ground. The sites form a gradient regarding the composition of the tree species ranging from a spruce dominated forest, mixed forests with increasing percentages of decidous trees to a stand with oak and beech only.

A total of 1396 Neuropterida were caught between 1995 to 1997 representing 44 species of Raphidiidae, Coniopterygidae, Hemerobiidae and Chrysopidae. Most species and specimens were caught with flight interception traps in the crown stratum. The assemblage of species differed from site to site and between tree species over all sites. Most species were caught on Quercus petraea followed by Larix decidua, Picea abies and Fagus sybuatica in a decreasing order. Eighteen species were seldom encountered. The more frequent species were divided into: i) coniferous associated species (10 sp.), ii) species of decidous trees $(7 \mathrm{sp}$.), and iii) species with no clear preference $(9 \mathrm{sp}$.).

\section{Key words}

Neuropterida, Raphidioptera, Coniopterygidae, Hemerobiidae, Chrysopidae, canopy fauna, spatial distribution, plant specificity

\section{Zusammenfassung}

In Wäldern unterschiedlicher Struktur wurde die Neuropteriden-Fauna mit Fallen im Kronenraum sowie in Bodennähe erfaßt. Die fünf Wälder bilden einen Gradienten hinsichtlich der Baumartenzusammensetzung, der vom fichtendominierten Wirtschaftswald über Wirtschaftswälder mit zunehmendem Laubholzanteil bis hin zu einem ungenutzten Laubwald reicht.

In den Jahren 1995 bis 1997 wurden insgesamt 1396 Neuropterida aus 44 Arten der Familien Raphidiidae, Coniopterygidae, Hemerobiidae und Chrysopidae gefangen. Die meisten Individuen und Arten traten in Lufteklektoren im Kronenraum auf. Die Artenzusammensetzung unterschied sich sowohl zwischen den Wäldern als auch zwischen den Baumarten. Die meisten Arten wurden auf Eiche (Quercus petraea) gefangen, gefolgt von Lärche (Larix decidua), Fichte (Picea abies) und Buche (Fagus sylvatica). 18 Arten traten in den Fängen selten auf. Die häufigeren Arte können in drei Gruppe eingeteilt werden, die i) vornehmlich auf Nadelhölzern, ii) vornehmlich auf Laubhölzern oder iii) auf beiden Gehölzarten gefangen wurden.

\footnotetext{
* Dedicated to Dr. Peter Ohm, Kiel $=18.07 .2001$
} 


\section{Introduction}

The knowledge on the assemblage of neuropterid species varies greatly for regional and national faunas. The fauna of Europe is one of the best-known (NEW, 1998) and many reviews on ecology, systematics and taxonomy exist (ASPÖCK et al., 1980, 1991; CANARD et al., 1984, 1998; NEW, 1986). But even here systematic investigations of regional faunas are lacking. The situation is the same in Germany, where some authors described well investigated faunas of several regions (GÜNTHER, 1991; GÜSTEN, 1993; KRAUSE \& OHM, 1970; RÖBER, 1990; TRÖGER, 1986) but between these, undersampled areas remain on the map (PRÖSE, 1992, 1995).

The autecology of most of the European species is known, i.e. the degree of association with specific habitats or plant species. These data are mainly drawn from specimens captured in the lower strata of the habitat (ASPÖCK et al., 1980; GEPP, 1973; MONSERAT \& MARÍN, 1992, 1994, 1996). Thus, crown living species are underrepresented.

The current data is one aspect of the comparision of ecosystems of commercial timberland and protected forest areas (AMMER et al., 1995; SCHUBERT, 1998; SCHUBERT et al., 1997; DETSCH, 1999). The assemblages of different insect taxa were determined in this project in the different strata of forest stands. Hereby, we present the data of Neuropterida. Specimens were sampled with a set of automatic traps in the crown stratum and near-ground. This kind of sampling has been rarely used to catch Neuropterida so far (BARSIG \& SIMON, 1995). Most investigations of neuropterid faunas were done by sweeping or beating the vegetation (BARNARD et al., 1986; GEPP, 1973; HOLLIER \& BELSHAW, 1992; MONSERAT \& MARÍN, 1992, 1994, 1996; PAULIAN, 1998; ZELENÝ, 1978), or used light traps (GREvE \& KOBRO, 1998; GÜNTHER, 1991; PAULIAN, 1996), coulored pan traps (CZECHOWSKA, 1985, 1994; SAURE \& KIELHORN, 1993) or knockdown sprays (BARNARD et al., 1986).

\section{Material and Methods}

The arthropods fauna of forest stands was investigated between 1995 and 1997. Samples were taken at five sites within a forest area of about 5,000 ha, the Hienheimer Forst

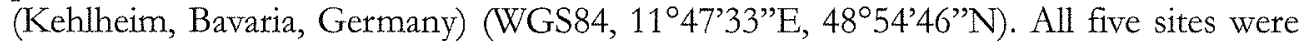
situated within approximately six kilometers and, therefore share the same conditions regarding altitude ( $410 \mathrm{~m}-465 \mathrm{~m}$ above sea level) geology, soil and climate. The geological subsoil consists of malme lime. This is covered by parabraunerde and terra fusca originating from loess deposits. The climate is subcontinental with an average annual temperature of $7.5-8.0^{\circ} \mathrm{C}$ (130 frost days) and an average annual percipitation of 650 $730 \mathrm{~mm}$ ( $55 \%$ during the growing period).

The potential natural vegetation is Asperulo-Fagetum with minor differences. The five sites form a gradient of tree species and average of age of the trees. The composition of the tree species ranges from a non-indigenious Picea abies (L.) Karst. dominated forest, via mixed forests with an increasing percentage of deciduous trees (Fagus sylvatica L., Quercus petraea Matt.) to a stand with huge Q. petraea and F. sylvatica only. Larix decidua Mill. occurs in two sites as admixture tree species with up to $13 \%$. The average age and the composition of the tree species within the stands is shown in table 1. 
Table 1: Average age of trees, composition of the tree species and number of traps at the fire forest sites investigated in the Hienheimer Forst (Southern Germany).

\begin{tabular}{|l|c|c|c|c|c|c|}
\hline & $\begin{array}{c}\text { Site } \\
\text { I }\end{array}$ & $\begin{array}{c}\text { Site } \\
\text { II }\end{array}$ & $\begin{array}{c}\text { Site } \\
\text { III }\end{array}$ & $\begin{array}{c}\text { Site } \\
\text { IV }\end{array}$ & $\begin{array}{c}\text { Site } \\
\text { V }\end{array}$ & $\begin{array}{c}\text { traps } \\
\text { per } \\
\text { three } \\
\text { species }\end{array}$ \\
\hline average age (years) & 80 & 106 & 103 & 132 & 356 & \\
\hline Picea abies & $95 \%$ & $56 \%$ & & $8 \%$ & & 9 \\
\hline Lariz decidua & & $13 \%$ & $11 \%$ & & & 6 \\
\hline Fagus sylvatica & $5 \%$ & $31 \%$ & $52 \%$ & $66 \%$ & $82 \%$ & 15 \\
\hline Quercus petraea & & & $35 \%$ & $26 \%$ & $18 \%$ & 9 \\
\hline traps per site & 6 & 9 & 9 & 9 & 6 & \\
\hline
\end{tabular}

Insects were caught with various different traps between April and October in the years 1995, 1996 and 1997. The traps consisted of flight interception traps, emergence traps and branch traps which catch walking specimens on a branch. The traps are described in detail by SCHUBERT (1998). The vessels of all traps contained formaldehyde solution (5\%) and were checked once a month. At each site three different trees per species were chosen for traps in the canopy layer. One flight interception trap and one branch trap were placed into the crown of the same tree. The height of the traps was 25-35 $\mathrm{m}$ above the ground depending on the crown architrcture. This design resulted in a different total amount of traps per tree species and site (Table 1). In addition to the traps in the crowns of the trees, there were one flight interception trap, one emergence trap and two branch traps (F. sylvatica) close to the soil sutface at each site. Additionally, we sampled insects by beating 25 branches of F. syliatica at all stands in August 1997.

Since the number of traps per site, tree species and stratum is inconsistant an overall statistical analysis is impossible. Thus, we used the catches of selected trap types for the different aspects. Regarding the abundance of the neuropterid species in the different forest sites, the numbers of specimens of all catches were summarized. The suitability of the different trap types to catch Neuropterida and their association to tree species was analysed on the basis of the crown traps only. The occurrence of species in the two strata, canopy layer or near-ground, was calculated with data of flight interception traps. We used $\mathrm{Chi}^{2}$-test to check for significance.

The nomenclature used is according to ASPÖCK et al. (1980) and BROOKS \& BARNARD (1990) for Neuroptera (exception: Anisochrysa syn. Dichochrysa; Coniopteryx pygmaea ENDERLEIN 1906 according to GÜNTHER, 1993) and according to ASPÖCK et al. (1991) for Raphidioptera. Females of the genus Coniopteryx were identified to the genus.

\section{Results}

During the three years of investigation 1396 adult Neuropterida were caught which represent 44 species. Four species, Coniopteryx hamatica, C. lentiae, Parasemidalis fuscipennis and Nineta principiae were recorded for the first time in Bavaria (PRÖSE, 1995). The number of species and specimens at each particular site is given in table 2 . No site included all 44 species. The highest number of species and specimens (39 sp./421 ind.) occurred at site III. The particular faunas (number of species) of the five forest sites did not 
Table 2: List of the species which were caught during the investigation at the five sites in Hienheimer Forst (Southern Germany).

\begin{tabular}{|c|c|c|c|c|c|c|}
\hline & $\begin{array}{l}\text { Site } \\
\text { I }\end{array}$ & $\begin{array}{l}\text { Site } \\
\text { II }\end{array}$ & $\begin{array}{l}\text { Site } \\
\text { IIII }\end{array}$ & $\begin{array}{l}\text { Site } \\
\text { IV }\end{array}$ & $\begin{array}{c}\text { Site } \\
\text { V }\end{array}$ & tota \\
\hline Raphidüidae (ind./spec.) & $5 / 3$ & $27 / 4$ & $34 / 6$ & $25 / 5$ & $16 / 4$ & $107 / 6$ \\
\hline Dichrostigma flatipes (STEIN 1863) & & 9 & 1 & 1 & & 1 \\
\hline Phaeostigma notata (FABRICIUS 1781) & 1 & 8 & 6 & 6 & 4 & 25 \\
\hline Puncha rateburgi(BRAUER 1876) & 1 & 4 & 6 & 2 & & 13 \\
\hline Subilla confinis (STEPHENS 1836) & & & 5 & & 2 & 7 \\
\hline Tenustoraphidic tigricoltis (ALBARDA 1891) & & & 8 & 6 & 8 & 22 \\
\hline Xonthosigmaxanthostigma (SCHUMMEL 1832) & 3 & 6 & 8 & 10 & 2 & 29 \\
\hline Coniopterygidae (ind./spec.) & $28 / 5$ & $127 / 6$ & $61 / 7$ & $130 / 8$ & $21 / 4$ & $367 / 10$ \\
\hline Conioptenx femates & 11 & 50 & 16 & 51 & 10 & 138 \\
\hline Coniopteryx boreatis TJEDER 1930 & & 5 & 14 & 12 & 5 & 36 \\
\hline $\begin{array}{l}\text { Conioptery hoematica MCLACHLAN } 1868 \\
\text { Coniontent }\end{array}$ & & & 1 & 2 & & 2 \\
\hline Coniopteryx pygmata ENDERLEIN 1906 & 4 & 38 & 9 & 48 & & 99 \\
\hline Contopteryx tineiform is CURTIS 1834 & & & 8 & 3 & 1 & 12 \\
\hline Conwentata pineticole ENDERLEN 1905 & 1 & 3 & 3 & & & 7 \\
\hline Conwentzia psocifomis (CuRTIS 1834) & & & & 1 & & 1 \\
\hline Helicocontis luted (WALLENGREN 1871) & 5 & 2 & & 4 & & 11 \\
\hline Parasemidalis, fuscipennis (REUTER 1894) & 3 & 25 & 2 & 3 & 2 & 35 \\
\hline Semidatis alevrodiformis (STEPHENS 1836) & 4 & 4 & 8 & 6 & 3 & 25 \\
\hline Hemerobiidae (ind./spec.) & $45 / 5$ & $111 / 11$ & $164 / 13$ & $84 / 9$ & $54 / 7$ & $458 / 14$ \\
\hline Drepantopteryx algida (ERICHSON 1851) & & 11 & 29 & & & 40 \\
\hline Drepanepteryx phaluenoides (LINNAEUS 1758) & 4 & 7 & 12 & 4 & 5 & 32 \\
\hline Hemerobius atrifronz MCLACHLAN 1868 & & 4 & 27 & 1 & & 32 \\
\hline Hemerobias fenestratus TJEDER 1932 & 1 & 1 & & & & 2 \\
\hline Hemerobius humutinzus LINNAEUS 1758 & & 5 & 5 & 1 & & 11 \\
\hline Hemerobius marginatus STEPHENS 1836 & & & 2 & & 1 & 3 \\
\hline Henerobius micans OLIVIER 1792 & 31 & 51 & 49 & 58 & 37 & 226 \\
\hline Hemerobitss pini STEPHENS 1836 & 7 & 12 & 5 & 1 & & 25 \\
\hline Sempherobius elegans (STEPHENS 1836) & & 1 & 3 & 5 & 1 & 10 \\
\hline Sympherobius klapateki ZELENY 1963 & & & 3 & 2 & 1 & 6 \\
\hline Sympherobius peltucidz: (WALKER 1853) & 2 & 11 & 22 & 12 & 9 & 56 \\
\hline Wesmaelits concinnus (STEPHENS 1836) & & & 1 & & & 1 \\
\hline Wesmatius quadrifasciatus (REUTER 1894) & & 8 & 6 & & & 14 \\
\hline Chrysopidae (ind./spec.) & $66 / 7$ & $88 / 9$ & $162 / 14$ & $77 / 12$ & $71 / 10$ & $464 / 15$ \\
\hline Chrysopa perfa (LINNAEUS 1758) & & 1 & & 1 & & 2 \\
\hline Chrysopa patlens (RAMBUR 1838) & & & 1 & 1 & & 2 \\
\hline Chropoperta carnea s.1. (STEPHENS 1836) & 17 & 14 & 95 & 54 & 41 & 221 \\
\hline Chryopidia ciliata (WESMAEL 1841) & 1 & 2 & 5 & 2 & 5 & 15 \\
\hline Cunctochyyst albolincata (KILLINGTON 1935) & & & 2 & 2 & & 4 \\
\hline Hypochysa elegans (BURMEISTER 1839) & 1 & 6 & 14 & 6 & 13 & 40 \\
\hline Dichochysaffavifrots (BRAUER 1850) & & 1 & 1 & 1 & & 3 \\
\hline Dichochrysa prasina (BURMEISTER 1839) & 2 & 5 & 17 & 3 & 2 & 29 \\
\hline Dichochrysa ventralis (CURTIS 1834) & & & 1 & & 1 & 2 \\
\hline Nineta flava (ScopoLi 1763) & & & 2 & 1 & 1 & 4 \\
\hline Nineta princtpitge MONSERRAT 1980 & & & 1 & & & 1 \\
\hline Nineta pallida (SCHNEDER 1851) & 2 & 3 & 2 & 1 & 1 & 9 \\
\hline Notochrysa capitata (FABRICIUS 1793) & 2 & 12 & 1 & & 1 & 16 \\
\hline Notochysa fulviceps (STEPHENS 1836) & & & 7 & 2 & 5 & 14 \\
\hline Peverimhoffina gracilis (SCHNEIDER 1851) & 41 & 44 & 13 & 3 & 1 & 102 \\
\hline $\begin{array}{r}\text { total specimens } \\
\text { species }\end{array}$ & $\begin{array}{c}144 \\
20\end{array}$ & $\begin{array}{c}353 \\
29\end{array}$ & $\begin{array}{c}421 \\
39\end{array}$ & $\begin{array}{c}316 \\
33\end{array}$ & $\begin{array}{c}162 \\
24\end{array}$ & $\begin{array}{r}1396 \\
44\end{array}$ \\
\hline
\end{tabular}


Table 3: Species which were caught with more than $75 \%$ on conifers or decidous trees or without preference. Only species with more than 5 specimens in the crown traps are regarded.

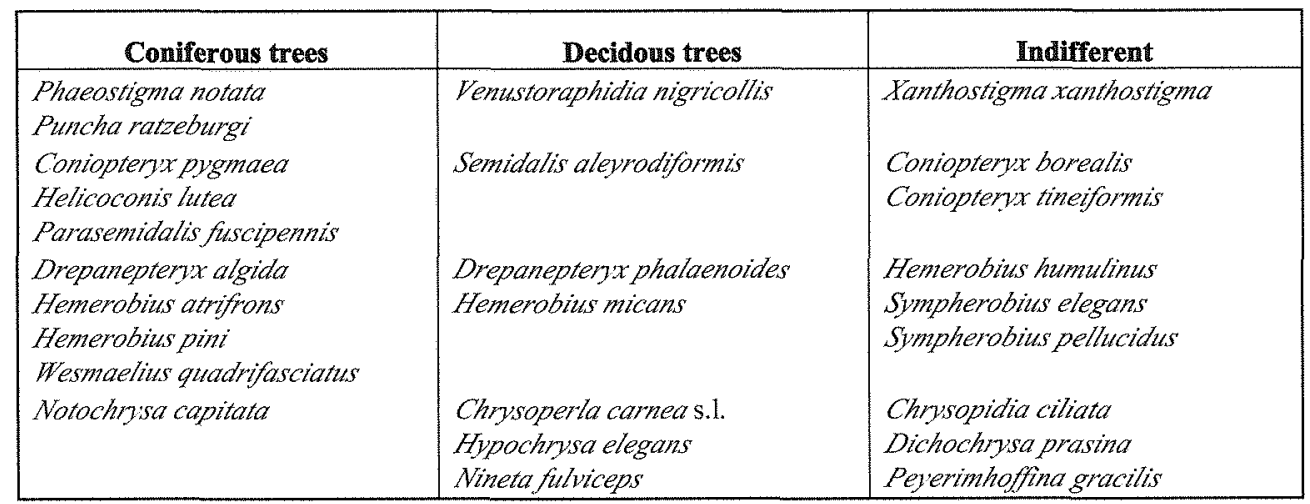

differ significantly ( $\left.\mathrm{Chi}^{2}=8.08, \mathrm{df}=4, \mathrm{p}=0.0887\right)$ but the numbers of specimens did $\left(\mathrm{Chi}^{2}=211.04, \mathrm{df}=4, \mathrm{p}=0.0000\right)$.

Regarding the occurrence of Neuropterida associated with the different tree species three groups can be defined, i.e. species of which more than $75 \%$ of all specimens were caught on $\mathbf{i}$ coniferous trees or $\mathbf{i i}$ decidous trees or iii species which were caught frequently on both (Table 3). No species was found on one tree species only. The closest association with one tree species was found for $D$. algida and $H$. atrifrons which were caught on $L$. decidua with $89.7 \%$ and $87.5 \%$ respectively and for $V$. nigricollis with $85.7 \%$ on Q. petraea.

The number of species and specimens caught on different tree species varies from 27 to 33 species and from 263 to 359 specimens. Since different numbers of traps were used, one has to focus on the number of species or specimens per trap. On $L$. decidua an average of 5.0 species per trap were recorded, followed by $Q$. petraea, $P$. abies and $F$. syluatica in a descending order (Table 4). The distribution of specimens confirms the attractiveness of $L$. decidua for Neuropterida.

The majority of specimens and species were caught with flight interception traps $(90.0 \%)$. Nevertheless, there were six species frequent $(>=20 \%$ ) in branch traps (Table 5). The other species did not reach $12 \%$ of the total in the branch traps. Due to the equal number of the two types of traps in the canopy layer it is possible to compare their suitability to catch Neuropterida. The catches differed significantly between flight interception traps and branch traps at the level of species $\left(\mathrm{Chi}^{2}=10.56, \mathrm{df}=1, \mathrm{p}=0.0012\right)$ and specimens $\left(\mathrm{Chi}^{2}=746.80, \mathrm{df}=1, \mathrm{p}=0.0000\right)$.

All 44 species were found in the canopy stratum with a total of 1168 specimens, compared to only 19 species with 206 specimens in the near-ground traps (Table 6). A statistical analysis of this distribution is not possible due to the different mumbers and types of traps. Calculating the total numbers to the average number per trap 1.1 and 3.8 species were caught near-ground and in the canopy layer respectively. The only species which was more abundant in the 'near-ground' traps was D. flatipes ( $72.7 \%$ near-ground). In the second year of the investigation, in August 1997, we sampled insects also by beating branches of F. sylvatica. At all sites the most abundant species (about $95 \%$ of all Neuropterida) were adults of $H$. micans and larvae of C. ciliata. 
Table 4: Occurrence of neuropterid species and specimens on the four different tree species.

\begin{tabular}{|c|c|c|c|c|}
\hline & $\begin{array}{l}\text { Fragras } \\
\text { spluatice }\end{array}$ & $\begin{array}{l}\text { Ouercus } \\
\text { petraea }\end{array}$ & $\begin{array}{l}\text { Picen } \\
\text { abies }\end{array}$ & $\begin{array}{l}\text { Larix } \\
\text { decidsca }\end{array}$ \\
\hline Raphidlidae (ind./spec.) & $1 / 1$ & $27 / 5$ & $21 / 3$ & $20 / 5$ \\
\hline Dichrostigma favipes (STEIN 1863 ) & & 2 & & 1 \\
\hline Phaeastigma notata (FABRICIUS 1781) & & 7 & 11 & 4 \\
\hline Puncha rateburgi (BRAUER 1876) & & & 5 & 6 \\
\hline Subilla confints (STEPHENS 1836) & & 3 & & \\
\hline Venusstoraphiatia nigricollis (ALBARDA 1891) & & 6 & & 1 \\
\hline Xatrthestigma xanthostigma (SCHUMMEL 1832) & 1 & 9 & 5 & 8 \\
\hline Coniopterygidae (ind./spec.) & $58 / 6$ & $53 / 8$ & $173 / 6$ & $83 / 6$ \\
\hline Conioptenyx females & 22 & 23 & 71 & 22 \\
\hline Conioptentr boreatis TIEDER 1930 & 12 & 9 & 5 & 10 \\
\hline Coniopteryx haematica MCLACHLAN 1868 & & 1 & & \\
\hline Contoptena lentiae H. ASPÖCK \& U. ASPOCK 1964 & & 2 & & \\
\hline Conioptentx pugmaea ENDERLEIN 1906 & 4 & 1 & 74 & 20 \\
\hline Coniopteryx tineiformis CURTIS 1834 & 5 & 2 & & 5 \\
\hline COnwentzicz pinericola ENDERLEN 1905 & & & 4 & 3 \\
\hline Conwentzic psociformis (CURTIS 1834) & & 1 & & \\
\hline Helicoconzis hutea (WALLENGREN 1871) & 2 & & 9 & \\
\hline Parasemidaliss fuscipennis (REUTER 1894) & 2 & 3 & 9 & 21 \\
\hline Semidalis alevrodiformis (STEPHENS 1836) & 11 & 11 & 1 & 2 \\
\hline Hemerobiidae (ind./spec.) & $189 / 9$ & $78 / 9$ & $45 / 9$ & $115 / 9$ \\
\hline Drepanepternix algida (ERICHSON 1851) & 3 & 1 & & 35 \\
\hline Drepancpterya phataenoides (LINNAEUS 1758) & 9 & 6 & 4 & 1 \\
\hline Hemerobius atrifions MCLACHLAN 1868 & & 3 & 1 & 28 \\
\hline Hemerobius fenestranus TILDER 1932 & & & 2 & \\
\hline Hemerobius frumushinus LINNAEUS 1758 & 3 & 5 & 3 & \\
\hline Hemerobizh marginatus STEPHENS 1836 & 2 & 1 & & \\
\hline Hemerobitus micans OLIVIER 1792 & 147 & 46 & 10 & 15 \\
\hline Hemerobins pint STEPHENS 1836 & 4 & & 11 & 5 \\
\hline Sympherobius elegans (STEPHENS 1836) & 3 & 4 & 2 & 1 \\
\hline Sympherobiis Klapaleki (ZELENY 1963) & 1 & 4 & & \\
\hline Sympherobius peltuciatus (WALKER 1853) & 17 & 8 & 9 & 19 \\
\hline Wesmaclius concinnus (STEPHENS 1836) & & & & 1 \\
\hline Hesmaelins quadrifasciatuss (REUTER 1894) & & & 3 & 10 \\
\hline Chrysopidae (ind./spec.) & $111 / 12$ & $105 / 11$ & $40 / 9$ & $49 / 10$ \\
\hline Chysopa perio (LINNAEUS 1758) & 1 & & & \\
\hline ChYYsopa pathens (RAMBUR 1838) & & & 1 & 1 \\
\hline Chrovoperla carnea s.1. (STEPHENS 1836) & 51 & 63 & 13 & 7 \\
\hline Chrosopidia citiatar (WESMAEL 1841) & 1 & 8 & 4 & 1 \\
\hline Cunctochrysa albolineata (KLLLINGTON 1935) & 3 & 1 & & \\
\hline Hypochnisu elegans (BURMEISTER 1839) & 21 & 6 & 2 & 8 \\
\hline Dichochrysaflarifrors (BRAUER 1850) & 1 & & & 2 \\
\hline Dichochinsa prasing (BURMEISTER 1839) & 8 & 9 & 3 & 7 \\
\hline Dichochrysa ventratis (CURTIS 1834) & 1 & & & \\
\hline Nineta flava (SCopou 1763) & & 4 & & \\
\hline Nincta principiae MONSERRAT 1980 & & 1 & & \\
\hline Nineta pallida (SCHNEIDER 1851 ) & 3 & 1 & 3 & 2 \\
\hline Notochrysa capitata (FABRICIUS 1793) & 2 & 1 & 2 & 10 \\
\hline Notochrysa fitulceps (STEPUENS 1836) & 5 & 6 & 1 & 2 \\
\hline Peyerimhoffina gracitis (SCHNEIDER 1851) & 14 & 5 & 11 & 9 \\
\hline total specimens & 359 & 263 & 279 & 267 \\
\hline specimens / trap & 23.9 & 29.2 & 31.0 & 44.5 \\
\hline total species & 28 & 33 & 27 & 30 \\
\hline species / trap & 1.9 & $\mathbf{3 . 7}$ & 3.0 & 5.0 \\
\hline
\end{tabular}


Table 5: Species which occurred frequently $(>=20 \%$ in the branch traps in the canopy.

\begin{tabular}{|l|c|c|}
\hline Species & Specimens total & $\begin{array}{c}\text { \% specimens } \\
\text { in branch traps }\end{array}$ \\
\hline Drepanepteryx algida (ERICHSON 1851) & 39 & $51.3 \%$ \\
\hline Hemerobius pini STEPHENS 1836 & 20 & $20.0 \%$ \\
\hline Chrysoperla carnea s.1. (STEPHENS 1836) & 134 & $32.1 \%$ \\
\hline Dichochrysa prasina (BURMEISTER 1839) & 27 & $33.3 \%$ \\
\hline Hypochinsa elegans (BURMEISTER 1839) & 37 & $27.0 \%$ \\
\hline Peyerimhoffina gracilis (SCHNEIDER 1851) & 39 & $30.8 \%$ \\
\hline
\end{tabular}

Table 6: Number of species and specimens which were caught in the canopy and neat-ground' with different typs of traps. Letters indicate significant differences between groups (see text).

\begin{tabular}{|l|l|c|c|}
\hline Number of & & canopy & near-ground \\
\hline Species & in branch trap & $18 \mathrm{a}$ & 12 \\
& in flight interception trap & $44 \mathrm{~b}$ & 12 \\
& total number & 44 & 19 \\
& number/trap & 3.8 & 1.1 \\
\hline \multirow{2}{*}{ Specimens } & in branch trap & $117 \mathrm{a}$ & 170 \\
& in flight interception trap & $1054 \mathrm{~b}$ & 36 \\
& total number & 1168 & 206 \\
\hline
\end{tabular}

\section{Discussion}

In the present article we describe the neuropterid fauna of five forest sites representing closed forest stands. Only site V and IV to a smaller amount were opened up by windbreakage in the early 1990's. Stands of this closed structure are suitable habitates for a relative low number of species whereas open woodlands are inhabited by much more species and bear a higher individual density (ASPÖCK et al., 1980). On the other hand there are some neuropterid species which are known to live in close coniferous stands or which prefere the canopy layer of forest stands. Some of these species were able to enlarge the area of their distribution in dependance on non-indigenious spruce afforestations in northern parts of Germany (OHM, 1973). In the literature there are only few investigations of the species assemblage of the canopy layer but no comparision of the canopy and the near-ground stratum. The canopy fauna of pine or mixed stands in Poland (CZECHOWSKA, 1985, 1994) yielded 22-28 species. In northern Germany SAURE \& KIELHORN (1993) caught 22 and 24 species on pine and oak trees respectively and BARSIG \& SIMON (1995) caught 13 species in the crowns of pine trees. GEPP (1973) yielded 35 species from a very diverse forest area in Austria over a period of eight years. The faunistical data cited above can not be compared directly with each other since the methods and duration of investigation differ highly (FRONTIER \& PICHOD-VIALE, 1995). However, we found a rich and diverse fauna of 44 species (20-39 species per site) within three years of investigation. This represents about half of the species known in Bavaria. A significant difference between the particular faunas within the sites was not expected because the greatest distance between two sites was about $6 \mathrm{~km}$. The sites with two tree species (site I and V) contained fewer species (20 and 24 sp.) than the others $(29,39,33$ $\mathrm{sp}$.). This effect might be due to the different numbers of traps as indicated by the lower 
numbers of specimens and of rare species ( $<10$ specimens in all years) in the catches of sites I and V (Table 2). Moreover, not only the number of tree species is important but also the species themselves. The most diverse fauna lives on $Q$. petraea and on $L$ decidua (33 and 30 species respectively) compared to $P$. abies (27 sp.) and F. sylvatica (28 sp.). It is surprising that such a low number of Neuropterida originates from $F$. sylvatica, the tree species which is indigenous in that region and plant association and which had the most traps in the crowns (Table 1). The high number of traps is clearly indicated by nearly 360 caught specimens. It is evident that even close forest stands are suitable habitats for many Neuropterida and that more diverse stands, i.e. higher number of tree species, are inhabited by more neuropterid species.

Seventeen species were rarely caught (i.e. $<=10$ specimens). C. psociformis, C. pallens and D. ventralis are eurytopic and show a clear preference to decidous trees like Quercus species. S. confinis, C. haematica, C. lentiae, S. klapaleki, D. flavifrons, and $N$. principiae are elements of the Mediterranean fauna which seem to be rare due to their temperature requirements. Two specimens of $N$. principiae have been recorded from Germany so far (SAURE, 1997, cited as Nineta guadarramensis principiae). The present individual shifts the distribution of this species to $48^{\circ} 54^{\prime} 46^{\prime \prime}$ northern latitude. H. marginatus, C. perla, C. albolineata, N. flava as well as $C$. pineticola, $H$. fenestratus, $W$. concinnus and $N$. pallida, the later group with a preference to coniferous trees, originate from the Siberian or European Extra-Mediterranean fauna. W. concinnus is mostly reported from Pinus (ASPÖCK et al., 1980) but the only specimen in this investigation was caught on $L$. decidua. The other species seem to need a denser vegetation and shrub layer. The rare occurrence of $H$. fenestratus even at site I and II is surprising. GRUPPE (1997) recorded it as an abundant species in closed forests of similar structure and tree composition ( $P$. abies, Abies alba, $Q$. petraea) in Southern Germany. All these rare species in addition to $D$. flavipes, are excluded from the following discussion of the host tree specificity, since the low number collected does not permit definite conclusion about plant specificity.

Species which prefered coniferous trees (Tab. 3) are mainly elements of the Siberian fauna (C. pygmaea, D. algida, $H$. atrifrons, $H$. pini, $W$. quadrifasciatus) or have a holarctic distribution ( $H$. lutea, $P$. fuscipennis). Only $N$. capitata, $P$. notata and $P$. ratzeburgi are ExtraMediterran European elements. $D$. algida, $H$. atrifrons, and $W$. quadrifasciatus are clearly associated with $L$ decidua with a decreasing order of association. Four specimens of $D$. algida were caught on $F$. sylivatica and $Q$. petraea, but all these trees were close enough to $L$. decidua for their crowns to touch.

Seven species were caught with more than $75 \%$ of their specimens on decidous trees (Table 3). Only $V$. nigricollis and $H$. elegans represent Mediterranean elements with high temperature requirements, as is the case with the Extra-Mediterranean-European elements $S$. aleyrodiformis and $N$. fulviceps. The two Hemerobiidae, D. phalaenoides and $H$. micans, actually come from Siberian regions and are usually associated with $F$. sylvatica.

Species with no clear preference for coniferous or decidous trees (Table 3) are mainly holarctic or of the Siberian fauna (X. xanthostigma, C. tineiformis, H. humulinus, C. ciliata). $C$. borealis, $S$. elegans, and $S$. pellucidus are Mediterranean species. The number of $C$. ciliata specimens does not represent the real abundance in these sites. Many larvae were beaten from the branches of F. sylvatica in all stands in August 1997. This species is a poor flyer and the set of traps is not adequate to catch this species in representative numbers. 
All species in our investigations were present in the catches of the crown traps, but only 19 species could be found in the near-ground traps. This obvious preference of the crown stratum indicates the thermophily of many Neuropterida at least in temperate climate zones (ASPÖCK et al., 1980). The close canopy of a forest can be seen as the upper surface of the stand similar to the forest edge. Here we find very diverse microclimatic conditions and high structural complexity close together. The radiation is high resulting in high temperatures in the sunny parts of the crown. Due to the roughness of the canopy wind is decelerated which results in higher humidity and weak gradients of humidity in the shadded areas, too (PARKER, 1995). Beside this abiotic factors we find different biological structures, for example leaves, small smooth-barked twigs, coarzebarked branches, limbs and dead wood of manifold dimensions. Although the suitability of edges varies with the insect taxon (OZANNE et al., 1997) this habitat seems to be suitable for many Neuropterida as well as for other arthropods which are used directly as prey or indirecly (honey dew) as food resource (ASPÖCK et al., 1980, 1991; ZELENÝ, 1984). A close host tree association of some Neuropterida is well known (AsPÖCK et al., 1980, 1991). For many species this association is indirect since larvae and adults are predators and the suitability of a host tree or even a certain habitat is determined by their feeding requirements (ZELENÝ, 1984). We have shown that most species seem to prefer the crown stratum of light-demanding trees as $L$. decidua and $Q$. petraea. The sparse crown of these tree species is characterized by warm and sunny microclimatic conditions especially if they occur sporadic in the closed canopy of a forest stand. Thus, it forms a kind of light tunnel which attracts many insects, prey and predators. The relative high number of species of Mediterranean origin which are assumed to have high temperature requirements indicates the favourable microclimate in the crowns of this group of tree species. The assemblage of Neuropterida in the higher strata of forest stands is poorly known. The most pragmatic way to get an idea of the fauna in this habitat is the use of automatic traps which can also be handled from the ground. Their efficiency depends on the behaviour of any particular species as explained for $C$. ciliata. Moreover, traps might also attract some species which hibernate as adults in protected niches like bark splits (HONEK, 1977; THIERRY et al., 1994). The use of flight interception traps and branch traps has at least three main advantages compared to the other techniques: (1) the environment is not disturbed or affected and the catches are continuously over a period of time at the same place, (2) the specimens are caught in the area of their main activity and (3) the specimens are not attracted. Thus, this technique gives an overview of the insect community of the area nearby the trap.

\section{Acknowledgements}

The work was funded by the Kuratorium der Bayerischen Landesanstalt für Wald und Forstwirtschaft and by the Stifterverband für die Deutsche Wissenschaft. We thank Dr. A. WITTINGTON for his linguistical help and Dr. D. THIERRY for his critical comments which helped the final draft.

\section{References}

AMMER, U; DETSCH, R. \& SCHULZ, U. 1995: Konzepte der Landnutzung. - Forstwissenschaftliches Centralblatt 114: 107-125.

Aspöck, H.; Aspöck, U. \& HölzEl, H. 1980: Die Neuropteren Europas Vol. 1 + 2, Goecke \& Evers, Krefeld, $495+355$ pp. 
AsPöCK, H.; AsPÖCK, U. \& Rausch, H. 1991: Die Raphidiopteren der Erde. Vol. 1 + 2, Goecke \& Evers, Krefeld, $730+550 \mathrm{pp}$.

BARNARD, P. C.; BROOKS, S. J. \& STORK, N. E. 1986: The seasonality and distribution of Neuroptera, Raphidioptera and Mecoptera on oaks in Richmond Park, Surrey, as revealed by insecticide knockdown sampling. - Journal of Natural History 20: 1321-1331.

BARSIG, M. \& SIMON, U. 1995: Vitalitätsänderungen von Kiefernnadeln und thre Auswirkungen auf die Phytophagenfauna. - Landschaftsentwicklung und Umweltforschung (Berlin) 98: 165 pp.

BROOKS, S. J. \& BARNARD, P. C. 1990: The green lacewings of the world: a generic review Neuroptera: Chrysopidae). - Bulletin of the British Museum of Natural History (Entomology) 59: 117-286.

CANARD, M.; SEMERIA, Y. \& NEW, T. R. 1984: Biology of Chrysopidae. Dt. W. Junk Publisher, The Hague, 294 pp.

CANard, M.; Cloupeau, R. \& Lerault, P. 1998: Les chrysopes du gene Nineta Navas 1912, en France (Neuroptera, Chrysopidae). - Bulletin de la Societe Entomologique de France 103: 327-336.

CzECHOWsKA, W. 1985: Neuropteran (Planipennia and Raphidioptera; Neuropteroidea) communities of coniferous forests in the Kampinoska forest and in Bialoleka Dworsa near Warsawa. - Fragmenta Faunistica 19: 391-401.

CZECHOWSKA, W. 1994: Neuropterans (Planipennia and Raphidioptera; Neuroptetoidea) of the canopy layer in pine forests. - Fragmenta Faunistica 23: 459-467.

DETSCH, R. 1999: Untersuchungen zur naturschutzfachlichen Bedeutung von Wirtschaftswald, dargestellt am Vergleich ausgewählter waldökologischer Parameter aus Naturwaldreservaten und Wirtschaftswäldern des Hienheimer Forstes (Kehlheim, Niederbayern). - PhD Thesis, Faculty of Forestry Munich, Germany.

FronTIER, S. \& PICHOD-VIALE, D. 1995: Ecosystemes: structure, functionnement, evolution. 2.ed. Masson, Paris: 447 pp.

GEPP, J. 1973: Vergleichend-quantitative Untersuchungen der Dichte von Neuropterenimagines in den Jahren 1964 bis 1972 im Kaiserwald südwestlich von Graz. - Berichte der Arbeitsgemeinschaft für ökologische Entomologie in Graz. 1: 29-41.

Greeve, L. \& KoBro, S. 1998: Preliminary data on abundance of phototactic Neuroptera and Raphidioptera in SE Norway as indicated by light-trap catches. - In: PANELIUS, S.: Neuropterology 1997, Acta Zoologica Fennica 209: 119-120.

GRUPPE, A. 1997: Beitrag zur Kenntnis der Planipennia (= Neuroptera) Oberbayerns. - Galathea 3. Supplement (Nürnberg) 7-10.

GÜNTHER, K. 1991: Echte Netzflüglet aus Lichtfängen im Stadtgebiet von Berlin (Insecta, Neuroptera). Entomologische Nachrichten und Berichte 35: 161-170.

GÜNTHER, K. 1993: Welche Art muß Coniopteryx parthenia ENDERLEIN 1906 heißen (Neuroptera, Coniopterygidae)? - Deutsche Entomologische Zeitschrift, N.F. 40: 167-171.

GÜSTEN, R. 1993: Beitrag zur Netzflügler-Fauna des Stadt- und Landkreises Bayreuth (Insecta: Neuropteroidea). - Berichte der Naturwissenschaftlichen Gesellschaft Bayreuth 22: 233-262.

HOLLIER, H. \& BELSHAW, R. D. 1992: Changes in Neuroptera assemblages in an old field succession in southern Britain. - The Entomologist 111: 187-194.

HONEK, A. 1977: The life cycle of Cbrysopa carnea STEPH. (Neuroptera) in Central Europe. - Acta entomologica bohemoslovaca 74: 60-62.

KRAUSE, R. \& OHM, P. 1970: Zur Neuropterenfauna der Sächsischen Schweiz I. - Faunistische Abhandlungen des Museums für Tierkunde Dresden 4: 25-30.

MONSERRAT, V. J. \& MARÍN, F. 1992: Substrate specifity of Iberian Coniopterygidae (Insecta: Neuroptera). - In: CANARD, M.; AsPÖCK, H. \& MANSELL, M. W.: Current reseatch in Neuropterology. Toulouse, France: $279-290$.

Monserrat, V. J. \& MARÍN, F. 1994: Plant substrate specifity of Iberian Chrysopidae (Insecta: Neuroptera). - Acta Oecologica 15: 119-131.

MONSERRAT, V.J. \& MARÍN, F. 1996: Plant substrate specifity of Iberian Hemerobiidae (Insecta: Neuroptera). - Journal of Natural History 30: 775-787.

NEW, T. 1986: A review of the biology of Neuroptera (Planipennia). - Neuroptera International 1: 1-57. 
NEW, T. 1998: Are Neuroptera an infomative focal group for conservation assessment? - In: PANELIUS, S.: Neutopterology 1997, Acta Zoologica Fennica 209: 167-174.

OHM, P. 1973: Durch die Forstwirtschaft ermöglichte Vergrößerung der Verbreitungsareale nadelholzbewohnender Netzflügler (Neuroptera, Planipennia). - Faunistisch-Ökologische Mitteilungen 4: 299-304.

OZANne, C. M. P.; Hambler, C.; Foggo, A. \& Speight, M. R. 1997: The significance of edge effects in the management of forests for invertebrate biodiversity. - In: LOWMAN, M. D. \& NADKARNI, N. M.: Forest canopies. Academic Press, San Diego, 534-550.

PARKER, G. G. 1995: Structure and microclimate of forest canopies. - In: LOWMAN, M. D. \& NADKARNI, N. M.: Forest canopies. Academic Press, San Diego, 73-106.

PAULIAN, M. 1996: Green lacewings from the southeast of the Rumanian Plain, as recorded by lighttrapping (Insecta: Neutoptera: Chrysopidae). - In: CANARD, M.; AsPÖCK, H. \& MANSELL, M. W: Pure and applied research in Neuropterology, 'Toulouse: 197-202.

PaULIAN, M. 1998: Occurrence of chrysopids (Neuroptera, Chrysopidae) and moving activity of their populations within a peach orchard agro-ecosystem in Rumania. - In: PANELIUS, S.: Neuropterology 1997, Acta Zoologica Fennica 209: 207-210.

PRöSE, H. 1992: Rote Liste gefährdeter Netzflügler (Neuropteroidea) Bayerns. - Schriftenreihe des Bayerischen Landesamt für Umweltschutz 111: 137-139.

PRÖSE, H. 1995: Kommentierte Artenliste der Netzflügler Bayerns (Insecta: Neuropteroidea). - Beiträge zur Bayerischen Entomofaunistik 1: 151-158.

RÖBER, H. 1990: Beiträge zur Biologie und Verbreitung einiget Familien der Neuropteren (Planipennia) in Westfalen. - Abhandlungen des Museums für Naturkunde Münster 52: 3-39.

SAURE, C. 1997: Nineta guadarramensis (PICTET, 1865) - eine für Deutschland neue Florfliege (Neuroptera: Chrysopidae). Galathea 3. Supplement (Nürnberg) 3-6.

SAURE, C. \& KIELHORN, K. H. 1993: Netzflügler als Bewohner der Kronenregion von Eiche und Kiefer (Neuroptera: Coniopterygidae, Hemerobiidae, Chrysopidae). - Faunistisch-Ökologische Mitteilungen 9/10: 391-402.

SCHUBERT, H. 1998: Untersuchungen zur Arthropodenfauna in Baumkronen - Ein Vergleich von Naturund Wirtschaftswäldern (Araneae, Coleoptera, Heteroptera; Neuroptetoidea; Hienheimer Forst, Niederbayern). - Wissenschaft \& Technik Verlag, Berlin, 154 pp.

SCHUBERT, H.; GRUPPE, A.; SCHULZ, U. \& AMnER, U. 1997: Baumkronenfauna von Natut- und Wirtschaftswäldern - Vergleich der Spinnen und Netzflügler (Araneae, Neuropteroidea). - Mitteilungen der Deutschen Gesellschaft für allgemeine und angewandte Entomologie 11: 683-687.

THIERRY, D.; ClOUPEAU, R. \& JARRY, M. 1994: Variation in the overwintering ecophysiological traits in the common green lacewing west Palearctic complex (Neuroptera, Chrysopidae). - Acta Oecologica 15: 593-606.

TRÖGER, E. J. 1986: Neuere Untersuchungen zur Neuropteren-Fauna in Südwestdeutschland. - In: GEPP, J.: Recent tesearch in Neuropterology, Graz: 131-136.

ZELENÝ, J. 1978: Les fluctuations spatio-temporelles des populations de Névropterès aphidiphages (Planipennia). - Annales de Zoologie, Ecologie Animale, 10: 359-366.

ZELENÝ, J. 1984: Chrysopid occurrence in west palearctic temperate forests and derived biotopes. - In: CANARD, M.; SEMERIA, Y. \& NEW, T. R.: Biology of Chrysopidae. The Hague, 151-159.

\section{Authors adresses:}

\section{Dr. AXEL GRuPPE}

Institute of Applied Zoology

Technische Universität München

Am Hochanger 13

85354 Freising, Germany

gruppe@zoo.forst.tu-muenchen.de

\section{HOLGER SCHUBERT}

Institute of Land Use Planing and Nature Conservation Technische Universität München

Am Hochanger 13

85354 Freising, Germany 